\title{
Investigation of The Effect of "Mouth Cancer Awareness Month" Events On Society with Google Trends ${ }^{\circledR}$
}

\author{
Oğuzhan Demirel(0000-0002-4756-6496) ${ }^{\alpha}$, Aslıhan Akbulut(0000-0001-7931-4464) $)^{\beta}$
}

Selcuk Dent J, 2021; 8: 802-807 (Doi: 10.15311/selcukdentj.855009)

Başvuru Tarihi: 06 Ocak 2021 Yayına Kabul Tarihi: 11 Mart 2021

\section{ABSTRACT}

Investigation of The Effect of "Mouth Cancer Awareness Month" Events On Society with Google Trends ${ }^{\circledR}$

Background: To create awareness about oral cancers, various events are being organized such as "oral cancer awareness month". Google Trends ${ }^{\circledR}$ is an application which is used to determine the relative frequency of a search term and is used for different purposes in the field of medicine, recently. The aim of this study is to determine the research popularity of terms about oral cancers using Google Trends ${ }^{\circledR}$ and to investigate the relationship between various awareness events.

Methods: Search Volume Indexes for terms "oral cancer" and "mouth cancer" for the USA, United Kingdom, and worldwide were obtained from Google Trends ${ }^{\circledR}$. Also, for Turkey "ağız kanseri", "dil kanseri", "dudak kanseri" and "damak kanseri" terms were used. Average search volume indexes of all terms for April, September and November, which are declared as oral cancer awareness months by different societies, were calculated.

Results: For terms, "mouth cancer" and "oral cancer", November averages in the United Kingdom and April averages in the USA were higher compared to all months $(p<0.05)$. Averages for "mouth cancer" and "oral cancer" were higher on November and April, respectively for worldwide $(p<0.05)$. No statistically significant relationship was observed between November, April, September averages and all months averages for "ağız kanseri", "dil kanseri", "dudak kanseri" and "damak kanseri" terms.

Conclusion: Awareness months are effective in the context of search volume index in United Kingdom, USA, and worldwide. In Turkey, awareness months may be organized or already existing events may be improved.

\section{KEYWORDS}

Oral cancer, Mouth cancer, Awareness

Cancers of oral cavity and oropharynx are seventh most common type of cancer. ${ }^{1}$ In Turkey, oral cavity cancers are the second most common head and neck malignancy, when the skin and thyroid cancers are excluded. $^{2}$

Although oral cancers are one of the most common cancers, awareness about this type of cancer is low. Results of surveys from different parts of the world, about society's awareness of oral cancers, range between $15.5 \%$ and $72 \% .^{3-8}$

In a study conducted in Turkey to determine the oral cancer awareness, results showed that $82 \%$ of

\section{öz}

"Ağız Kanseri Farkındalık Ayı" Etkinliklerinin Toplum Üzerindeki Etkisinin Google Trends ${ }^{\circledR}$ ile Değerlendirilmesi

Amaç: Ağız kanserleri hakkında farkındalık yaratmak amacıyla, 'ağız kanseri farkındalık ayı' gibi çeşitli etkinlikler düzenlenmektedir. ${ }^{\circledR}$ Bu çalışmada Google Trends ${ }^{\circledR}$ kullanılarak ağız kanserleri ile ilgili terimlerin aranma popülaritesinin değerlendirilmesi ve çeşitli ağız kanseri farkındalık etkinlikleri ile ilişkilerinin incelenmesi amaçlanmıştır.

Gereç ve Yöntemler: Google Trends ${ }^{\circledR}$ uygulamasından, "oral cancer" ve "mouth cancer" terimlerinin ABD, Birleşik Krallık ve dünya genelinde arama hacim indeksleri elde edildi. Türkiye için de; "ağız kanseri", "dil kanseri", "dudak kanseri" ve "damak kanseri" terimleri kullanıldı. Farklı topluluklar tarafından organize edilen etkinlik ayları olan Nisan, Eylül ve Kasım aylarında ilgili terimler için arama hacim indeksleri hesaplandı.

Bulgular: "Mouth cancer" ve "oral cancer" terimleri için Kasım ayı arama hacim indeksleri Birleşik Krallık' ta ve Nisan ayı arama hacim indeksleri ABD' de diğer ayların ortalamalarından yüksek bulundu $(p<0.05)$. Dünya genelinde, "mouth cancer" ve "oral cancer" terimleri için arama hacim indeksleri iki terim için sırasıyla Kasım ve Nisan aylarında yüksek bulundu $(p<0.05)$.

Sonuç: Arama hacim indeksi değerleri bağlamında incelendiğinde, farkındalık ayları $A B D$, Birleşik Krallık ve Dünya genelinde etkili etkinliklerdir. Türkiye' de de ağız kanserleri için farkındalık ayları düzenlenebilir ya da mevcut etkinlikler daha ileri düzeye taşınabilir.

\section{ANAHTAR KELIMELER}

Oral kanser, Ağız kanseri, Farkındalık

participants had not heard about oral cancer. Most of individuals who heard about oral cancer, had information from television or internet. ${ }^{9}$

To improve society's awareness about oral cancers, various campaigns all around the world are organized. Oral Cancer Awareness Month is April in USA and held out since 1999. November is Mouth Cancer Action Month held out in UK. Head and Neck Cancer Awareness Week is organized by The European Head and Neck Society (EHNS) in September since 2013.

Google Trends ${ }^{\circledR}$ application is used to evaluate the search intensity of a given topic, at a specified time

\footnotetext{
${ }^{\alpha}$ Bolu Abant İzzet Baysal University, Faculty of Dentistry, Department of Oral and Maxillofacial Radiology Bolu, Turkey.

$\beta$ Medipol University, Faculty of Dentistry, Department of Oral and Maxillofacial Radiology İstanbul, Turkey.
} 
interval, in a specified region. The application provides numerical values called, search volume index (SVI), which range from 0 to 100 according to the ratio of the search term's search frequency to all other calls. A value of '100' indicates the time period in which the search term is most popular, and a value of ' 0 ' indicates that there is not enough data for search term. ${ }^{10}$ For example; if we are interested in the popularity of a search term, ' $X$ ', worldwide, between 2018 and 2019, we will have a search volume index value '100' when the term is most popular. Other search volume indexes, among the time period, will be determined, accordingly. Google Trends ${ }^{\circledR}$ application provide search volume indexes, not the number of total calls; so it may be thought that, results obtained from the application are independent from internet use amount.

Recently, Google Trends ${ }^{\circledR}$ is used for various medical studies such as; to define the interest on treatment procedures, ${ }^{11}$ to determine the popularity of medical products on different times of the year, ${ }^{12}$ to define the public interest on disaeases, ${ }^{13}$ etc.

Results of a Google Trends ${ }^{\circledR}$ study, investigating the efficiency of Mouth Cancer Awareness Day organized in Ireland; showed that search volumes for oral cancer and mouth cancer terms significantly increase on September when the awareness day is held out. ${ }^{14}$

Google trends ${ }^{\circledR}$ have been used in another study conducted to define the impact of campaigns and awareness days for different types of cancers on public's internet search activity. Results of the study showed that, except breast cancer, public interest for various types of cancers increase with events that famous figures experienced or with medical advancements that are covered in media. ${ }^{10}$

It is stated that, search data obtained from Google Trends $^{\circledR}$ are reliable and complementary source for epidemiologic and public health research. ${ }^{15}$

Aim of this study is to define the impact of oral cancer awareness campaigns, in Turkey and in different countries on public's internet search interest using Google Trends ${ }^{\circledR}$.

\section{MATERIALS AND METHODS}

Search volume indexes (SVI) were obtained from Google Trends ${ }^{\circledR}$ for terms "oral cancer" and "mouth cancer". Date range for search volume indexes was adjusted as between 01.01.2004 and 21.11.2019. Locations for search terms were set as USA, UK and worldwide. At this point, six search volume index data set (for two terms and three locations), for 191 months (16 years) since 01.01.2004 were achieved (Figure 1).

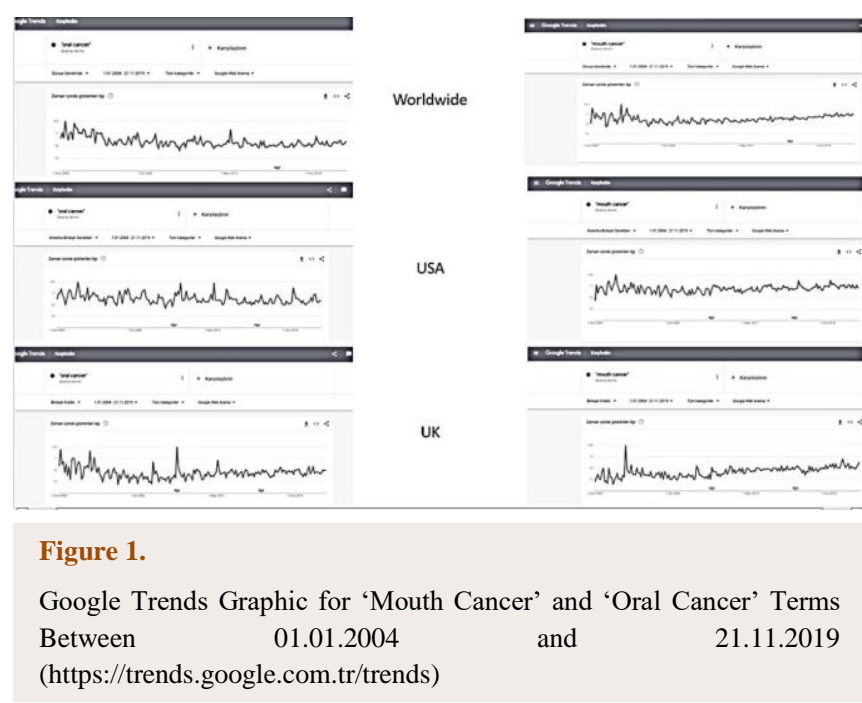

Average SVI for 16 November and 16 April months since 2004 were calculated on every SVI data set. Also, average values of 191 months were recorded for two terms and three locations. Another data set was obtained using the same method described above for the terms "tongue cancer", "lip cancer" and "palate cancer".

Another Google Trends $^{\circledR}$ evaluation was made for location 'worldwide' for the same search terms. Date range was adjusted between 01.01.2013 and 21.11.2019 (2013 was selected as the start point because it is the date, The European Head and Neck Society announced Head and Neck Cancer Awareness Week on September). Two search volume index data set for 83 months were obtained with this method (Figure 2).

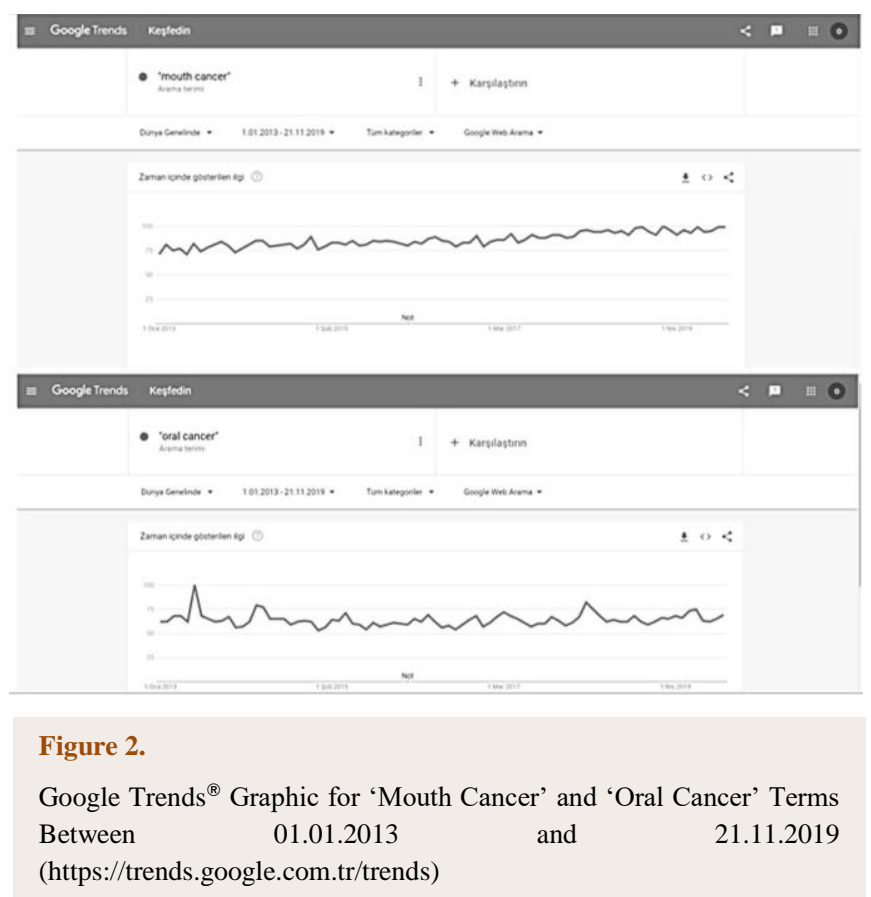


Average SVI for 7 November, 7 April and 7 September months since 2013 were calculated. Average values for 83 months for both search terms were recorded. SVI data set for "tongue cancer", "lip cancer" and "palate cancer" terms were also obtained for the same date range and worldwide location.

Strategy for obtaining SVI data sets is illustrated in Figure 3.

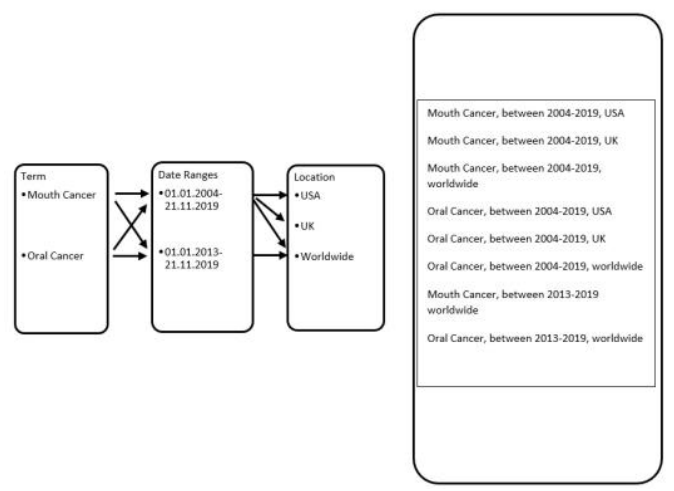

Figure 3.

Strategy For Obtaining SVI Data Sets

For the evaluation of the efficiency of oral cancer awareness months in Turkey; Google Trends ${ }^{\circledR}$ was used for the terms in Turkish language "ağız kanseri" (mouth cancer), "dil kanseri" (tongue cancer), "dudak kanseri" (lip cancer), "damak kanseri" (palate cancer). Date ranges were adjusted between 01.01.2004-21.11.2019 and 01.01.2013-21.11.2019. Location was set as Turkey and as a result, a total of eight search volume index data sets were obtained (4 search terms and 2 date ranges). Averages were calculated for 16 November and 16 April months from the search volume index data beginning from 2004 and for 7 November, 7 April and 7 September months from the search volume index data beginning from 2013.

For the statistical analysis of the relationship between above mentioned month averages and general averages for every search term, for every location and for every time interval, z-test was used. Significance level was set $p<0.05$.

\section{RESULTS}

Table 1 demonstrates average SVI values of November, April, September and all months.

For every search term used, results are represented below:

\subsection{Mouth cancer}

Between 2004 and 2019, average SVI of 16 November months for UK and worldwide and average SVI of 16 April months for USA, were
Table 1.

\section{Average SVI values of November, April, September and All Months}

\begin{tabular}{|c|c|c|c|c|c|c|c|c|c|}
\hline $\begin{array}{l}\text { Search } \\
\text { Term }\end{array}$ & Date Interval & Area & $\begin{array}{l}\text { Average } \\
\text { General } \\
\text { SVI }\end{array}$ & $\begin{array}{c}\text { Average } \\
\text { November SVI }\end{array}$ & $z p$ & $\begin{array}{l}\text { Average } \\
\text { Appril } \\
\text { SVI }\end{array}$ & $z p$ & $\begin{array}{l}\text { Average } \\
\text { September } \\
\text { SVI }\end{array}$ & $z p$ \\
\hline $\begin{array}{l}\text { "mouth } \\
\text { cancer" }\end{array}$ & $\begin{array}{l}01.01 .2004 \\
21.11 .2019\end{array}$ & UK & 41.39 & 51.68 & 32933 & 41.43 & 0.015 & & \\
\hline & & & & & 0086 & & 2706 & & \\
\hline $\begin{array}{l}\text { "mouth } \\
\text { cancer" }\end{array}$ & $\begin{array}{l}01.01 .2004 \\
21.11 .2019\end{array}$ & USA & 62.14 & 62.31 & $\begin{array}{l}0.086 \\
0.928\end{array}$ & 67.43 & $\begin{array}{c}2706 \\
0.006^{*}\end{array}$ & & \\
\hline $\begin{array}{l}\text { "mouth } \\
\text { cancer" }\end{array}$ & $\begin{array}{l}01.01 .2004 \\
21.11 .2019\end{array}$ & Worldwide & 60.95 & 66 & $\begin{array}{l}2508 \\
0.012^{*}\end{array}$ & 63 & $\begin{array}{l}1018 \\
0.307\end{array}$ & & \\
\hline $\begin{array}{l}\text { "mouth } \\
\text { cancer" }\end{array}$ & $\begin{array}{l}01.01 .2013 . \\
21.11 .2019\end{array}$ & Worldwide & 84.64 & 88.42 & $\begin{array}{l}1349 \\
0.177\end{array}$ & 85.14 & $\begin{array}{l}1784 \\
0.85\end{array}$ & 83.14 & $\begin{array}{l}-0.535 \\
0.589\end{array}$ \\
\hline $\begin{array}{c}\text { "oral } \\
\text { cancer" }\end{array}$ & $\begin{array}{l}01.01 .2004 . \\
21.11 .2019\end{array}$ & USA & 60.8 & 60.56 & $\begin{array}{c}-0.095 \\
0.92\end{array}$ & 71.43 & $\begin{array}{l}4248 \\
0.000^{*}\end{array}$ & & \\
\hline $\begin{array}{l}\text { "oral } \\
\text { cancer" }\end{array}$ & $\begin{array}{l}01.01 .2004 \\
21.11 .2019\end{array}$ & UK & 40.84 & 47.87 & $\begin{array}{l}2208 \\
0.027^{\star}\end{array}$ & 42.68 & $\begin{array}{l}0.58 \\
0.56\end{array}$ & & \\
\hline $\begin{array}{l}\text { "oral } \\
\text { cancer" }\end{array}$ & $\begin{array}{l}01.01 .2004 \\
21.11 .2019\end{array}$ & Worldwide & 57.37 & 57.25 & $\begin{array}{c}-0.049 \\
0.96\end{array}$ & 64.37 & $\begin{array}{l}2864 \\
0.004^{*}\end{array}$ & & \\
\hline $\begin{array}{l}\text { "oral } \\
\text { cancer" }\end{array}$ & $\begin{array}{l}01.01 .2013- \\
21.11 .2019\end{array}$ & Worldwide & 62.48 & 62.28 & $\begin{array}{l}-0.077 \\
0.936\end{array}$ & 69.85 & $\begin{array}{c}2866 \\
0.004^{*}\end{array}$ & 60 & $\begin{array}{l}-0.964 \\
0.337\end{array}$ \\
\hline $\begin{array}{l}\text { "tongue } \\
\text { cancer" }\end{array}$ & $\begin{array}{l}01.01 .2004 \\
21.11 .2019\end{array}$ & UK & 34.91 & 36.25 & $\begin{array}{l}0.275 \\
0.779\end{array}$ & 42.31 & $\begin{array}{l}1524 \\
0.18\end{array}$ & & \\
\hline $\begin{array}{l}\text { "tongue } \\
\text { cancer" }\end{array}$ & $\begin{array}{l}01.01 .2004 \\
21.11 .2019\end{array}$ & USA & 42.08 & 37.37 & $\begin{array}{l}-1558 \\
0.118\end{array}$ & 46.12 & $\begin{array}{l}1336 \\
0.18\end{array}$ & & \\
\hline $\begin{array}{l}\text { "tongue } \\
\text { cancer" }\end{array}$ & $\begin{array}{l}\begin{array}{l}01.01 .2004 \\
21.11 .2019\end{array}\end{array}$ & Worldwide & 52.10 & 49.75 & $\begin{array}{l}-0.821 \\
0.412\end{array}$ & 54.56 & $\begin{array}{l}0.859 \\
0.389\end{array}$ & & \\
\hline $\begin{array}{l}\text { "tongue } \\
\text { cancer" }\end{array}$ & $\begin{array}{l}01.01 .2013- \\
21.11 .2019\end{array}$ & Worldwide & 55.63 & 55.71 & $\begin{array}{l}0.025 \\
0.976\end{array}$ & 55.71 & $\begin{array}{l}0.025 \\
0.976\end{array}$ & 55.42 & $\begin{array}{l}-0.066 \\
0.944\end{array}$ \\
\hline "lip cancer" & $\begin{array}{l}01.01 .2004 \\
21.11 .2019\end{array}$ & uk & 13.54 & 15.68 & $\begin{array}{l}0.602 \\
0.548\end{array}$ & 25.56 & $\begin{array}{c}3381 \\
0.000^{*}\end{array}$ & & \\
\hline "lip cancer" & $\begin{array}{l}01.01 .2004 \\
21.11 .2019\end{array}$ & USA & 26.82 & 44371 & $\begin{array}{l}-0.936 \\
0.347\end{array}$ & 27.31 & $\begin{array}{l}0.166 \\
0.86\end{array}$ & & \\
\hline "lip cancer" & $\begin{array}{l}01.01 .2004- \\
21.11 .2019\end{array}$ & Worldwide & 25.24 & 22.81 & $\begin{array}{l}-0.847 \\
0.395\end{array}$ & 25.68 & $\begin{array}{l}0.153 \\
0.880\end{array}$ & & \\
\hline "lip cancer" & $\begin{array}{l}\text { O1.01.2013- } \\
21.11 .2019\end{array}$ & Worldwide & 71.07 & 65.00 & $\begin{array}{l}-1298 \\
0.193\end{array}$ & 75.47 & $\begin{array}{l}0.941 \\
0.347\end{array}$ & 75.28 & $\begin{array}{l}0.900 \\
0.368\end{array}$ \\
\hline $\begin{array}{l}\text { "palate } \\
\text { cancer" }\end{array}$ & $\begin{array}{l}01.01 .2004 \\
21.11 .2019\end{array}$ & UK & 31079 & 27426 & $\begin{array}{c}-47 \\
0.960\end{array}$ & 31990 & $\begin{array}{c}2882 \\
0.003^{*}\end{array}$ & & \\
\hline $\begin{array}{l}\text { "palate } \\
\text { cancer" }\end{array}$ & $\begin{array}{l}01.01 .2004 \\
21.11 .2019\end{array}$ & USA & 18445 & 18445 & $\begin{array}{l}0.000 \\
1000\end{array}$ & 18445 & $\begin{array}{l}0.000 \\
1000\end{array}$ & & \\
\hline $\begin{array}{l}\text { "palate } \\
\text { cancer" }\end{array}$ & $\begin{array}{l}\begin{array}{l}01.01 .2004 \\
21.11 .2019\end{array}\end{array}$ & Worldwide & 17.82 & 17.18 & $\begin{array}{l}-0.163 \\
0.872\end{array}$ & 15.75 & $\begin{array}{l}-0.527 \\
0.596\end{array}$ & & \\
\hline $\begin{array}{l}\text { "palate } \\
\text { cancer" }\end{array}$ & $\begin{array}{l}\begin{array}{l}01.01 .2013- \\
21.11 .2019\end{array}\end{array}$ & Worldwide & 36.80 & 45.14 & $\begin{array}{l}1206 \\
0.226\end{array}$ & 30.28 & $\begin{array}{l}-0.943 \\
0.347\end{array}$ & 31.71 & $\begin{array}{l}-0.736 \\
0.459\end{array}$ \\
\hline $\begin{array}{c}\text { "ağıız } \\
\text { kanseri" }\end{array}$ & $\begin{array}{l}\begin{array}{l}01.01 .2004 \\
21.11 .2019\end{array}\end{array}$ & Turkey & 9272 & 7 & $\begin{array}{l}-0.759 \\
0.447\end{array}$ & 25020 & $\begin{array}{l}-0.532 \\
0.596\end{array}$ & & \\
\hline $\begin{array}{c}\text { "ağız } \\
\text { kanseri" }\end{array}$ & $\begin{array}{l}\text { 01.01.2013- } \\
\text { 21.11.2019 }\end{array}$ & Turkey & 60.17 & 57.85 & $\begin{array}{l}-0.433 \\
0.667\end{array}$ & 63.71 & $\begin{array}{l}0.66 \\
0.509\end{array}$ & 53.28 & $\begin{array}{l}-1286 \\
0.197\end{array}$ \\
\hline "dil kanseri" & $\begin{array}{l}01.01 .2004 \\
21.11 .2019\end{array}$ & Turkey & 13.71 & 16.62 & $\begin{array}{l}0.847 \\
0.395\end{array}$ & 16.68 & $\begin{array}{l}0.864 \\
0.389\end{array}$ & & \\
\hline "dil kanserr" & $\begin{array}{l}01.01 .2013- \\
21.11 .2019\end{array}$ & Turkey & 36.93 & 33.57 & $\begin{array}{l}-0.646 \\
0.515\end{array}$ & 33.14 & $\begin{array}{l}-0.729 \\
0.465\end{array}$ & 40 & $\begin{array}{l}0.591 \\
0.555\end{array}$ \\
\hline $\begin{array}{l}\text { "dudak } \\
\text { kanseri" }\end{array}$ & $\begin{array}{l}\begin{array}{l}01.01 .2004 \\
21.11 .2019\end{array}\end{array}$ & Turkey & 44426 & 23.18 & $\begin{array}{l}1768 \\
0.07\end{array}$ & 20.75 & $\begin{array}{l}0.926 \\
0.352\end{array}$ & & \\
\hline $\begin{array}{l}\text { "dudak } \\
\text { kanserr" }\end{array}$ & $\begin{array}{l}\text { 01.01.2013- } \\
\text { 21.11.2019 }\end{array}$ & Turkey & 59 & 66 & $\begin{array}{l}1207 \\
0.226\end{array}$ & 59.28 & $\begin{array}{c}0.048 \\
0.96\end{array}$ & 54.42 & $\begin{array}{l}-0.789 \\
0.429\end{array}$ \\
\hline $\begin{array}{l}\text { "damak } \\
\text { kanseri" }\end{array}$ & $\begin{array}{l}01.01 .2004 \\
21.11 .2019\end{array}$ & Turkey & 6 & 44351 & $\begin{array}{l}-0.802 \\
0.423\end{array}$ & 24959 & $\begin{array}{l}-0.132 \\
0.896\end{array}$ & & \\
\hline $\begin{array}{l}\text { "damak } \\
\text { kanseri" }\end{array}$ & $\begin{array}{l}\begin{array}{l}01.01 .2013- \\
21.11 .2019\end{array}\end{array}$ & Turkey & 32.99 & 35.28 & $\begin{array}{l}0.397 \\
0.689\end{array}$ & 39 & $\begin{array}{l}1044 \\
0.298\end{array}$ & 36.42 & $\begin{array}{l}0.595 \\
0.548\end{array}$ \\
\hline
\end{tabular}

SVI: Search Volume Index

significantly higher than all months' average SVI $(p<0.05)$.

Between 2013 and 2019, at worldwide level, no statistically significant difference between November, April and September averages and all months' averages was observed $(p>0.05)$. 


\subsection{Oral Cancer}

Between 2004 and 2019, SVI averages of 16 April months were found to be higher for USA and worldwide than all months' average SVI $(p<0.05)$. For UK, average SVI of November months were significantly higher than all months' $(p<0.05)$.

As date range is adjusted between 2013 and 2019, for worldwide; average SVI of 7 April months were significantly higher than all months' averages $(p<0.05)$. No such relationship was detected between November and September averages and all months' averages $(p>0.05)$.

\subsection{Tongue Cancer, Lip Cancer and Palate Cancer}

Statistically significant difference was observed for the term "lip cancer" and "palate cancer" in the UK. Average SVI values of 16 April months were significantly higher than all month's averages for both terms when the date range was adjusted between 2004 and 2019. November, April and September average SVI values showed no significant difference from all month's averages for "tongue cancer" search term in either location or date range.

3.4 Ağız Kanseri, Dil Kanseri, Dudak Kanseri, Damak Kanseri (Terms About Oral Cancers in Turkish Language)

No statistically significant relationship between November average SVI, April average SVI and September average SVI and all months' average SVIs, was observed for Turkey location and for both date ranges $(p>0.05)$.

\section{DISCUSSION}

Because most of the oral tissues are visible by individuals, self-examination is a convenient tool for early detection of oral cancers. ${ }^{16}$ Primary requirement for effective usage of self-examination is awareness of oral cancers.

Cancer awareness weeks are organized for different types of cancer all around the world to improve public interest on cancer and to emphasize the importance of cancer screening. In context of oral cancers; various organizations take role in improving oral cancer awareness. In this study, our primary goal was to define the efficacy of oral cancer awareness days by determining the public's internet search activity, using Google Trends ${ }^{\circledR}$ tool.

Murray et al's research utilizing Google Trends $^{\circledR}$ to investigate the effectiveness of oral cancer awareness day organized in Ireland showed that, peak activity for search term 'mouth cancer' was on September, the month that awareness day takes place. Also, they compared two search terms, mouth cancer and oral cancer, and pointed out that internet search using 'mouth cancer' term was significantly higher than the term 'oral cancer'. ${ }^{14}$

In this study, search terms used were, 'mouth cancer' and 'oral cancer'. Mouth Cancer Action Month is organized on November in United Kingdom and Oral Cancer Awareness Month is organized on April in United States. In United Kingdom, for both search terms, average SVI values for November were higher than all months' averages; same situation was evident in USA, with one difference that April averages were higher. No comparison between 'mouth cancer' and 'oral cancer' search terms is made in this research; however, as the results indicate, both terms had higher values on when awareness months are organized. As the location is set 'worldwide' on Google Trends ${ }^{\circledR}$; for 'mouth cancer' search term, average SVI was significantly higher on November, no significant difference was observed on April. In contrary, for the search term 'oral cancer', average SVI was higher on April and no difference was evident on November. These controversies between terms may be explained by the names of awareness months that 'Oral Cancer' Awareness Month is held out on April and 'Mouth Cancer' Action Month on November.

An interesting research conducted by Kaleem et al, investigated the effect of media or celebrity related news on internet research activity for various cancer types. Breast cancer, lung cancer, colon cancer, rectal cancer, prostate cancer, pancreatic cancer, endometrial cancer, cervical cancer, brain cancer and glioblastoma were the search terms that they were interested in. They looked for peak months when the search activity for each term were at highest level and mediatic events occured on peak months. Results of the study indicated that nearly for all cancer types, peak months were involving media news involving known figures who experience the cancer or news about a new treatment modality. However, breast cancer had peaks on October, the month that is proclaimed 'breast cancer awareness month'. ${ }^{10}$

In this study, primary goal was to define the effectiveness of awareness campaigns and results pointed out the success of awareness months in United Kingdom, United States and worldwide in context of internet search activity. However, no relationship was observed in Turkey as Google Trends $^{\circledR}$ investigation was made in Turkish language. Interestingly, when a Google search 
including 'ağız kanseri farkındalık ayı'- meaning 'oral cancer awareness month' in English- only three results are evident on Google in first three pages. With a little effort to explain the situation mentioned above in Kaleem et al's study ${ }^{10}$ and a little deeper glance at the dates where the graph had its peak values in Turkey; 'tongue cancer' research term had its peak on June 2019 when the date range is set between 2013 and 2019. There were two news on the internet media; one describing treatment of a person who had been on the news with at least some sensation and the other one about a case with a headline 'she learned that she had cancer when her tooth is broken'. On March 2018, the month where one of the peaks on the graph was, the date a famous actor passed away, because of tongue cancer.

As mentioned before; in Esen et al's survey conducted in Turkey, results showed that $82 \%$ of individuals had no information about oral cancers. ${ }^{9}$ This situation necessitates more action for promotion of oral cancers and from the results of this study, it may be concluded that, awareness months are effective methods for improvement of public interest. In Turkey, foundations and universities try to take role on campaigns such as Oral and Dental Health Week celebrated on November or Turkish Ear Nose Throat and Head and Neck Surgery Society announces Head and Neck Cancer Awareness Week in cooperation with The European Head and Neck Society.

\section{CONCLUSION}

Results of this study, shows that awareness months are efficient campaigns for improving public interest about oral cancers. In Turkey, campaigns such as awareness months should be promoted to improve knowledge and interest of society about oral cancers. 


\section{REFERENCES}

1. Kebabcıoğlu Ö, Pekiner FN. Assessing Oral Cancer Awareness Among Dentists. J Cancer Educ 2018;33(5):1020-6.

2. Düzlü $M$, Karamert R, Bakkal FK, Cevizci R, Tutar $\mathrm{H}$, Zorlu ME, et al. The demographics and histopathological features of oral cavity cancers in Turkey. Turk J Med Sci 2016; 46(6):1672-6.

3. Tomar SL, Logan HL. Florida adults' oral cancer knowledge and examination experiences. J Public Health Dent. 2005;65(4):221-30.

4. Wimardhani YS, Warnakulasuriya S, Subita GP, Soegyanto Al, Pradono SA1 Patoni N. Public awareness of oral cancer among adults in Jakarta, Indonesia. J Investig Clin Dent 2019; 10(1): e12379.

5. Azimi S, Ghorbani Z, Ghasemi E, Tennant M, Kruger E. Disparities in Oral Cancer Awareness: a Population Survey in Tehran, Iran. J Cancer Educ. 2019;34(3):535-41.

6. Monteiro LS, Warnakulasuriya S, Cadilhe S, Sousa D, Trancoso PF, Antunes L, et al. Oral cancer awareness and knowledge among residents in the Oporto city, Portugal. J Investig Clin Dent. 2016;7(3):294-303.

7. Al-Maweri SA, Tarakji B, Alsalhani AB, Al-Shamiri $\mathrm{HM}$, Alaizari NA, Altamimi MA, et al. Oral cancer awareness of the general public in Saudi Arabia. Asian Pac J Cancer Prev 2015; 16(8):3377-81.

8. Eltayeb AS, Satti A, Sulieman AM. Oral Cancer Awareness in Sudan: Assessment of Knowledge, Attitude and Treatment Seeking Behavior. Asian Pac J Cancer Prev 2017; 18(6):1645-9.

9. Esen A, Gürses G, Güler A, Baştürk F. Ağız Kanseri Bilinç Düzeyinin Türk Hastalarda Değerlendirilmesi. J Tradit Complem Med 2018;1:99-104.

10.Kaleem T, Malouff TD, Stross WC, Waddle MR, Miller DH, Seymour AL et al. Google Search Trends in Oncology and the Impact of Celebrity Cancer Awareness Cureus 2019; 11 (8): e5360.

11. Whipple LA, Kotamarti VS, Heiman AJ, Patel A, Ricci JA. Using Google Trends to analyze patient search interest in implant-based and autologous breast reconstruction. Breast J 2019; doi: 10.1111/tbj.13675.

12. Mimura W, Akazawa M. The Association Between Internet Searches and Moisturizer Prescription in Japan: Retrospective Observational Study. JMIR Public Health Surveill 2019; 5(4): e13212.

13.Wu GC, Cao F, Shen HH, Hu LQ, Hu Y, Sam NB. Global public interest in systemic lupus erythematosus: an investigation based on internet search data. Lupus 2019;28:1435-40.

14. Murraya G, O'Rourk C, Hogana J, Fentona JE. Detecting internet search activity for mouthcancer in Ireland. Br J Oral Maxillofac Surg 2016;54:1635.
15. Ryan PM, Ryan CA. Mining Google Trends Data for Health Information: The Case of the Irish "Cervical Check" Screening Programme Revelations. Cureus 2019 11(8): e5513.

16.Elango KJ, Anandkrishnan N, Suresh A, lyer SK, Ramaiyer SK, Kuriakose MA. Mouth self-examination to improve oral cancer awareness and early detection in a high-risk population. Oral Oncol 2011 47(7):620-4.

\section{Corresponding Author:}

Aslihan AKBULUT

Medipol University

Faculty of Dentistry

Department of Oral and Maxillofacial Radiology

İstanbul, Turkey

Phone : +90 5065355190

E-mail : aakbulut@medipol.edu.tr 